\title{
KEY DURABILITY ISSUES WITH MULLITE-BASED ENVIRONMENTAL BARRIER COATINGS FOR Si-BASED CERAMICS
}

\author{
Kang N. Lee* \\ Chemical Engineering Department \\ Cleveland State University \\ Cleveland, $\mathrm{OH}$
}

\begin{abstract}
Plasma-sprayed mullite $\left(3 \mathrm{Al}_{2} \mathrm{O}_{3} 2 \mathrm{SiO}_{2}\right)$ and mullite/yttria-stabilized-zirconia (YSZ) dual layer coatings have been developed to protect silicon-based ceramics from environmental attack. Mullite-based coating systems show excellent durability in air. However, in combustion environments, corrosive species such as molten salt or water vapor penetrate through cracks in the coating and attack the Si-based ceramics along the interface. Thus themodification of the coating system for enhanced crack-resistance is necessary for long-term durability in combustion environments. Other key durability issues include interfacial contamination and coating/substrate bonding. Interfacial contamination leads to enhanced oxidation and interfacial pore formation, while weak coating/substrate bonding leads to rapid attack of the interface by corrosive species, both of which can cause premature failure of the coating. Interfacial contamination can be minimized by limiting impurities in coating and substrate materials. The interface may be modified to improve the coating/substrate bond.
\end{abstract}

\section{INTRODUCTION}

Silicon-based ceramics are promising candidates for hot section structural components of heat engines and heat exchanger tubes for industrial furnaces. One potential barrier to such applications is their environmental durability. The excellent oxidation resistance of silicon-based ceramics at high temperatures in clean, dry oxygen is due to the formation of a solid, protective external silica scale. However, the normally protective silica scale can be degraded by reacting with impurities, such as alkali salts [1,2] or water vapor [3-5].

Molten $\mathrm{Na}_{2} \mathrm{SO}_{4}$ can deposit in gas turbine engines operating near marine environments or from contaminants in the fuel [6]. The $\mathrm{Na}_{2} \mathrm{SO}_{4}$ then reacts with the silica to form liquid sodium silicate, leading to accelerated degradation of Si-based ceramics [1]. In coal-fired combustion environments, combustion gases contain low levels of alkali salts because of naturally occurring minor alkali components in the coal. These alkali salts can dissolve in the silica scale and enhance the transport of oxygen, leading to drastically enhanced oxidation [2]. In heat engines, substantial amounts of water vapor, typically about $10 \%$, is 9 f 5 deced from buming hydrocarbon fuels in air [7]. The water vapor reacts with silica, forming gaseous hydroxide species, such as $\mathrm{Si}(\mathrm{OH})_{4}[3,5]$. In high pressure combustion environments, the higher water vapor pressure generates even higher levels of gaseous hydroxide species, resulting in linear volatilization of silica. The linear volatilization of silica coupled with the parabolic oxidation of Si-based ceramics results in overall paralinear kinetics [4], causing rapid degradation of Si-based ceramics. Therefore, the realization of the full potential of silicon-based ceramics in high temperature structural applications depends on the development of environmental protection schemes.

An external environmental barrier coating is a promising approach to protect Si-based ceramics from environmental attack. Mullite is a promising candidate coating material because of its close coefficient of thermal expansion (CTE) match and good chemical compatibility with Si-based ceramics. Researchers at Solar Turbines, Inc., San Diego, CA, and Oak Ridge National laboratory, Oak Ridge, TN, have done pioneering work on applying refractory oxide coatings such as alumina, zirconia, yttria, mullite, cordierite, etc., on $\mathrm{SiC}[8,9]$. In those studies, mullite was found to be adherent and offer the best protection of all the refractory coatings tested. However, those plasma-sprayed mullite coatings tended to crack on thermal cycling. Researchers at NASA Lewis Research Center, Cleveland, $\mathrm{OH}$, identified the crystallization of amorphous phase mullite, wich accompaniès volumetric contraction, as the main source for the cracking of plasma-sprayed mullite coatings [10]. Based on this finding, researchers at NASA LeRC successfully eliminated most of the amorphous phase mullite from the coating by spraying the mullite while heating the $\mathrm{SiC}$ substrate above the crystallization temperature of amorphous mullite $\left(\sim 1000^{\circ} \mathrm{C}\right)[10]$.

These second generation mullite coatings provide excellent protection in air and molten salt environment [10-14]. Mullite coatings, however, suffer selective vaporization of silica in the presence of water vapor because of its high silica activity $(0.3 \sim 0.4)[11,15,16]$. Thus, an environmental overlay coating is required when protection from water vapor is needed. Yttria-stabilized zirconia (YSZ) was selected as a baseline overlay coating because of its proven performance as a thermal barrier coating (TBC) in combustion environments. The mullite coating in the mullite/YSZ coating system is somewhat analogous to the bond coat in conventional TBC's, in the sense that it provides bonding as well as oxidation protection. This paper will discuss the current durability issues of second generation mullite-based environmental coatings on $\mathrm{Si}$-based ceramics and future research directions in this area.

\footnotetext{
* Resident Research Associate at NASA Lewis Research Center
}

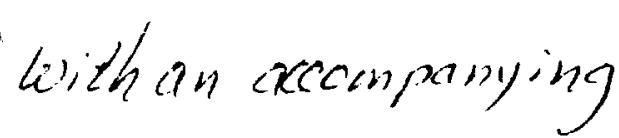




\section{EXPERIMENTAL}

Mullite and YSZ coatings were applied by atmospheric pressure plasma spraying onto $2.5 \times 0.6 \times 0.15 \mathrm{~cm}$ sintered $\alpha-S i C$ coupons (Hexoloy ${ }^{\mathrm{TM}}$, Carborundum, Niagara Falls, NY) and reaction bonded silicon nitride (RBSN, R. Bhatt, NASA LeRC). The SiC substrates were roughened $\left(\mathrm{R}_{\mathrm{a}}{ }^{* *}=5-6 \mu \mathrm{m}\right)$ by etching in $\mathrm{Na}_{2} \mathrm{CO}_{3}$ to achieve a good mechanical bond [10], whereas RBSN was used as processed. Fused mullite powder with the particle size of 44-74 $\mu \mathrm{m}$ was used (Cerac, Inc., Milwaukee, WI). Typical coating thickness was 100-200 $\mu \mathrm{m}$ for the mullite coating and $50 \mu \mathrm{m}$ for the YSZ coating. Details of the coating parameters are described elsewhere [10]

Coated coupons were annealed in air at $1300^{\circ} \mathrm{C}$ for $100 \mathrm{~h}$, prior to the environmental exposure. Environmental exposures were thermal cycling in air, thermal cycling in $90 \% \mathrm{H}_{2} \mathrm{O} / \mathrm{O}_{2}$ at 1 atm (simulated lean combustion environments) or isothermal exposure in high pressure burner rigs with or without molten salt. Thermal cycling tests in water vapor were to, evaluate the long-term behavior of coatings in lean combustion environments because high pressure burner rigs are fot suitable for long-term tests due to their high operating cost. Thermal cycling was performed using an automated thermal cycling furnace. Each thermal cycle consisted of $2 \mathrm{~h}$ at temperature, rapid cooling to room temperature, and $20 \mathrm{~m}$ in at room temperature. Typically, samples reached the high temperature within $2 \mathrm{~min}$ and the low temperature within $5 \mathrm{~min}$ in each cycle. Molten salt environments were generated using a high pressure burner rig with Jet $A$ fuel containing $2 \mathrm{ppm} \mathrm{Na}$ at $4 \mathrm{~atm}$.

Tested samples were mounted in epoxy, polished to $1 \mu \mathrm{m}$ using diamond suspension, and examined using Scanning Electron Microscopy (SEM) and Energy Dispersive Spectroscopy (EDS)

\section{ENVIRONMENTAL DURABILITY Chosen}

Air

Mullite/YSZ-coated $\mathrm{SiC}$ was exposed to a $2 \mathrm{~h}$ thermal cycling expostre in air at $1300^{\circ} \mathrm{C}$. Figure 1 shows the cross-section after $500 \mathrm{~h}$ exposure. Mullite coatings typically developed through-thickness cracks, however, they maintained excellent adhesion and provided excellent oxidation protection. Mullite-coated $\mathrm{SiC}$ exhibited a similar behavior under the same exposure, indicating that the presence of YSZ overlay coating did not affect the coating durability despite the large CTE mismatch between the two layers.

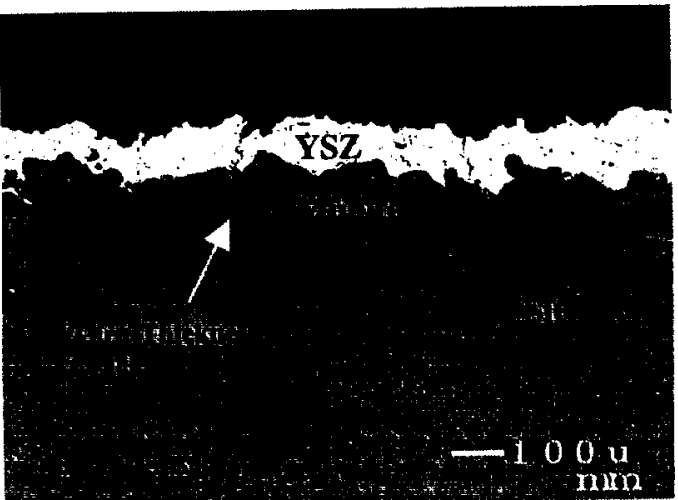

Fig. 1. Mullite/YSZ-coated SiC after 500h with$2 \mathrm{~h}$ cycles at $1300^{\circ} \mathrm{C}$ in air.

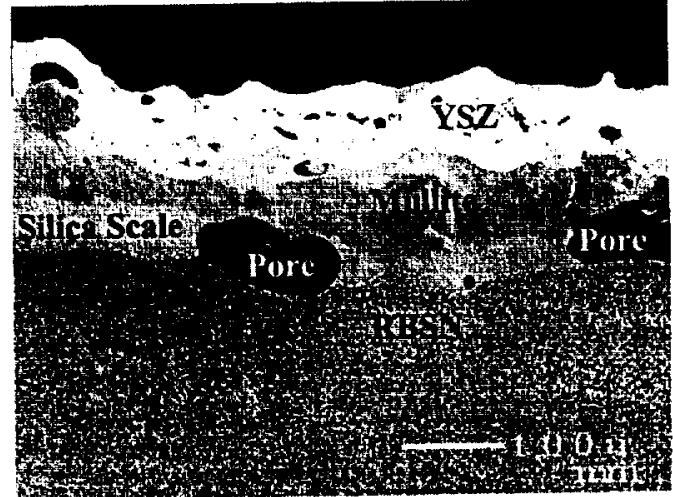

Fig. 2. Mullite/YSZ-coated RBSN after $50 \mathrm{~h}$ at $1300^{\circ} \mathrm{C}$ in air.

Mullite/YSZ-coated RBSN was exposed to 1 isothermal oxidation at $1300^{\circ} \mathrm{C}$ in air for $50 \mathrm{~h}$. A thick oxide scale and large pores developed at the mullite/RBSN interface (Fig. 2). EDS showed a significant amount of Mg in the scale. This contamination by MgO, the RBSN, is responsible for the enhanced oxidation and pore formation. Similar enhanced oxidation and pore formation of mullite-coated $\mathrm{SiC}$ was observed when the system was contaminated by $\mathrm{Na}_{2} \mathrm{O}$ or $\mathrm{K}_{2} \mathrm{O}$ from the coating processed with a low purity mullite powder [17]. Alkali and alkaline earth metal oxides are known to degrade the oxidation, resistance of Si-based ceramics, by enhancing the oxygen transport through silica by altering the silica petwork [18].

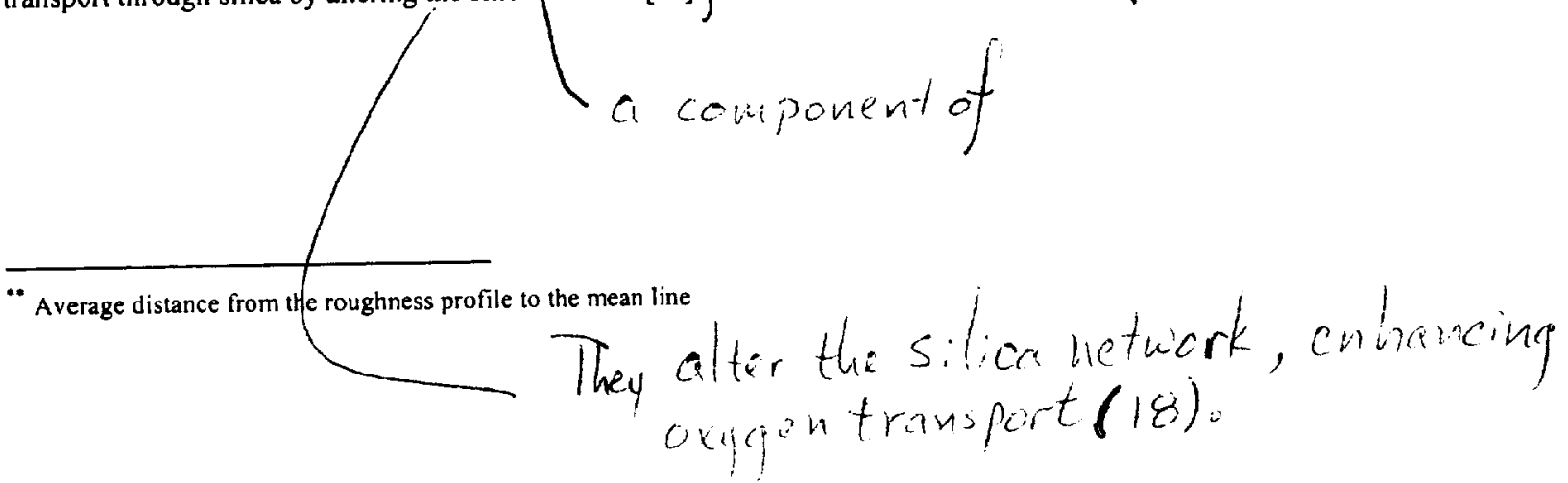




\section{Combustion Environments}

( in is

High Pressure Burner Rig: Uncoated, mullite-coated and mullite/YSZ-coated SiC was exposed t6 high pressure burner rig (HPBR) under a rich burn condition (equivalence ratio=1.9) at $6 \mathrm{~atm}$ and $1230^{\circ} \mathrm{C}$. Figure 3 shows the plot of weight change vs. time. Uncoated and mullite-coated $\mathrm{SiC}$ showed weight loss due to the volatilization of silica. The lack of weight change in the mullite/YSZ-coated $\mathrm{SiC}$ indicated that the YSZ overlay coating provided ffé protection from water vapor. Figure $4 \mathrm{a}$ shows the cross-section of mullite-coated $\mathrm{SiC}$ after the high pressure burner rig exposure. Pores are observed at the interface where cracks intersected the $\mathrm{SiC}$ interface. Enhanced oxidation was observed around pores, indicating that water vapor penetrated through the cracks and reacted with $\mathrm{SiC}$. The pore formation is attributed to the generation of gaseous silicon hydroxide species. The selective volatilization of silica from mullite left a porous layer of alumina on the mullite (Fig. 4b)
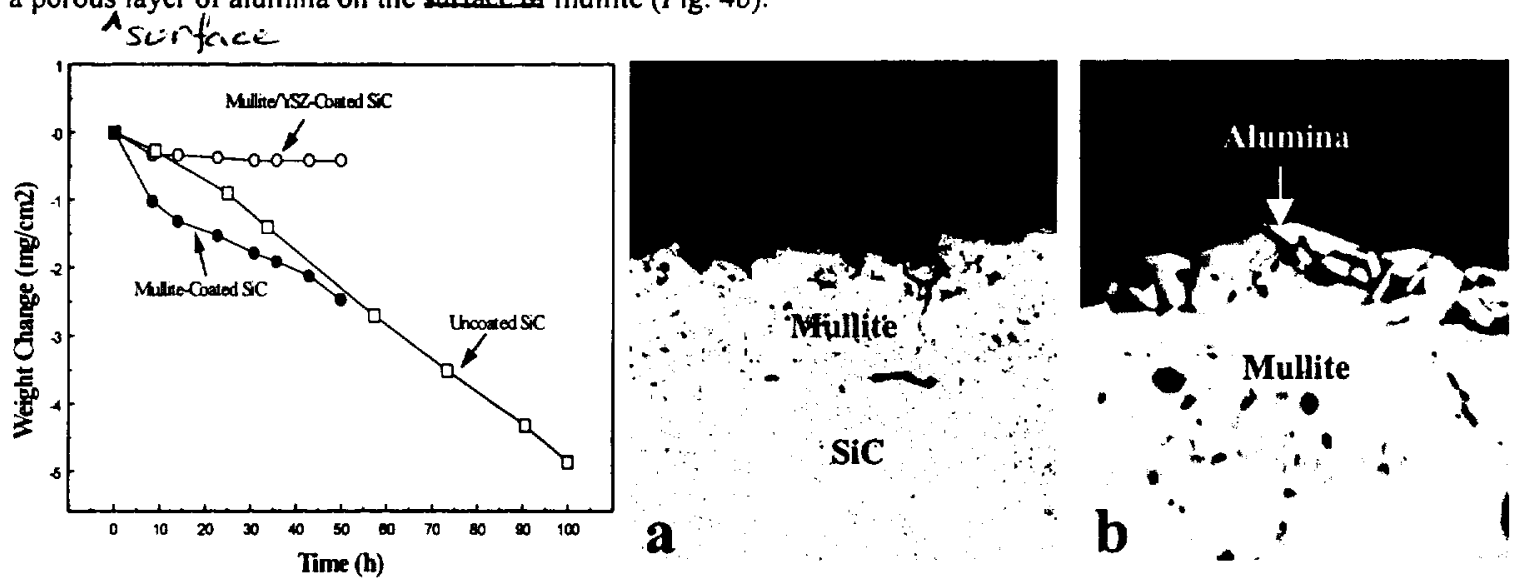

Fig. 3. Weight change vs. time for coated and uncoated SIC in HPBR

Fig. 4. Mullite-coated SiC after $50 \mathrm{~h}$ in HPBR (6atm, $\left.1230^{\circ} \mathrm{C}\right)$. (6atm, $\left.1230^{\circ} \mathrm{C}\right)$.

Water Vapor Cyclic Furnace: Mullite-coated SiC/SiC (Dupont Lanxide, Newark, DE) exposed to $2 \mathrm{~h}$ cycle exposure in $50 \% \mathrm{H}_{2} \mathrm{O} / \mathrm{O}_{2}$ at $1300^{\circ} \mathrm{C}$ showed weight loss, whereas mullite/YSZ-coated $\mathrm{SiC} / \mathrm{SiC}$ exhibited parabolic oxidation [19] The weight loss of mullite-coated $\mathrm{SiC} / \mathrm{SiC}$ was attributed to the selective volatilization of silica from mullite. This result is consistent with the weight change behavior of mullite and mullite/YSZ coatings in high pressure burner rig (Fig. 3). A similar weight change behavior is expected for these coatings on sintered $\mathrm{SiC}$ in water vapor cyclic furnace because the surface reaction should not be affected by the type of substrates.

Mullite/YSZ-coated $\mathrm{SiC}$ was exposed to $2 \mathrm{~h}$ cycle exposure in $90 \% \mathrm{H}_{2} \mathrm{O} / \mathrm{O}_{2}$ at $1300^{\circ} \mathrm{C}$ to evaluate the longterm durability in lean combustion environments. Most interfacial areas showed excellent adherence with limited oxidation after 100h. However, at some interfacial areas, where through-thickness-cracks intersected the SiC interface, accelerated oxidation initiated (Fig. 5a). After $200 \mathrm{~h}$, accelerated oxidation propagated along the entire mullite/SiC interface, forming a thick porous silica scale (Fig. 5b). Water vapor, the predominant oxidant in a $\mathrm{H}_{2} \mathrm{O} / \mathrm{O}_{2}$ environment, is known to enhance the oxidation of $\mathrm{SiC}$. The silica scale formed in high water vapor is porous, allowing the oxidation to propagate readily along the interface. The porous scale is attributed to the generation of gaseous silicon hydroxide species. This is in contrast to the scale formed in dry air where the scale is dense and thus prevents the rapid propagation of oxidation.

The effect of preoxidation on the coating adherence was evaluated by preoxidizing a $\mathrm{SiC}$ coupon at $1300^{\circ} \mathrm{C}$ for $100 \mathrm{~h}$ in, prior to the application of mullite/YSZ coating. The coated coupon was exposed to $90 \% \mathrm{H}_{2} \mathrm{O} / \mathrm{O}_{2}$ at $1250^{\circ} \mathrm{C}$ with $2 \mathrm{~h}$ cycles. The cross-section after $100 \mathrm{~h}$ showed that the entire interface was attacked by water vapor, forming a thick porous silica scale (Fig. 6). It is believed that the silica scale from preoxidation weakened the mullite/SiC bonding, leading to more rapid penetration by water vapor than in the coupon without preoxidation. Preoxidation did not affect the durability of the system when exposed in air.

Hot Corrosion Rig: Uncoated and mullite-coated $\mathrm{SiC}$ coupons were exposed in a hot corrosion burner rig at $1000^{\circ} \mathrm{C}$ for $50 \mathrm{~h}$. Prior to the hot corrosion exposure, the coated coupon underwent 600 one hour thermal cycles at $1200^{\circ} \mathrm{C}$ in air to let cracks from. Uncoated $\mathrm{SiC}$ was severely deformed due to the attack by the molten salt, whereas mullite-coated $\mathrm{SiC}$ was well preserved (Fig. 7a). Cross-section of the mullite-coated $\mathrm{SiC}$ showed that mullite/SiC interface was fairly intact (Fig. 7b). Only a limited attack with glassy reaction products, presumably sodium silicates, was observed at the interface where cracks intersected the $\mathrm{SiC}$ interface (Fig. 7c). This is an indication of the penetration of salt through some cracks.

$$
\text { Cuss-sectioning }
$$



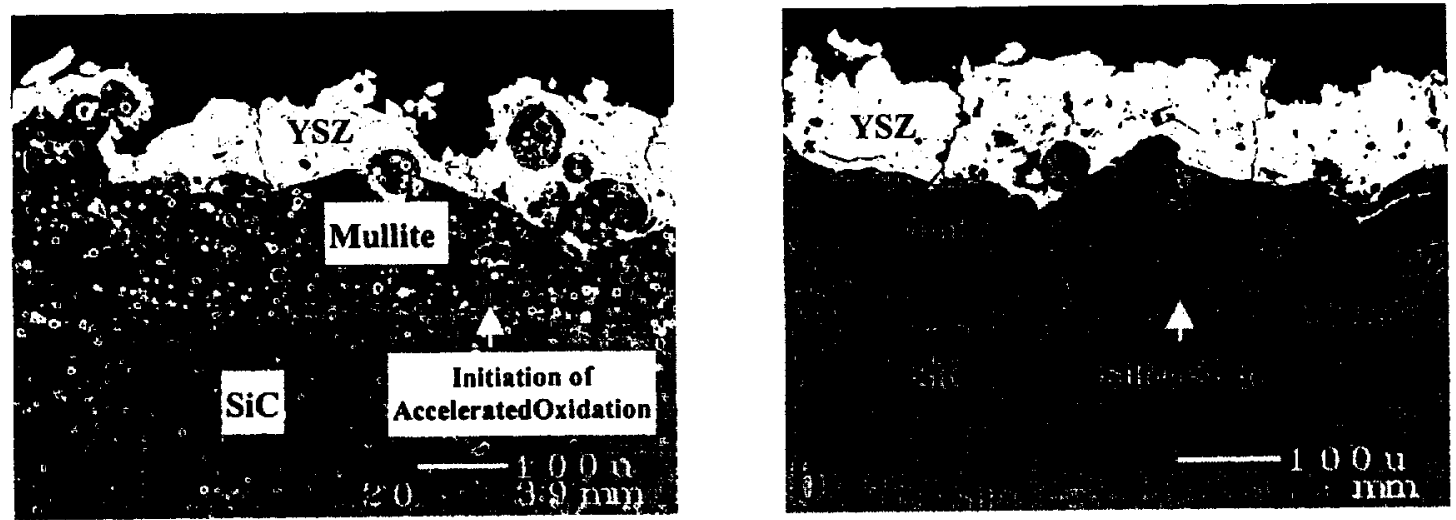

Fig. 5. Mullite/YSZ-coated SiC exposed to $2 \mathrm{~h}$ cycle exposure in $90 \% \mathrm{H}_{2} \mathrm{O} / \mathrm{O}_{2}$ at $1300^{\circ} \mathrm{C}$. (a: 100h; b: 200h)
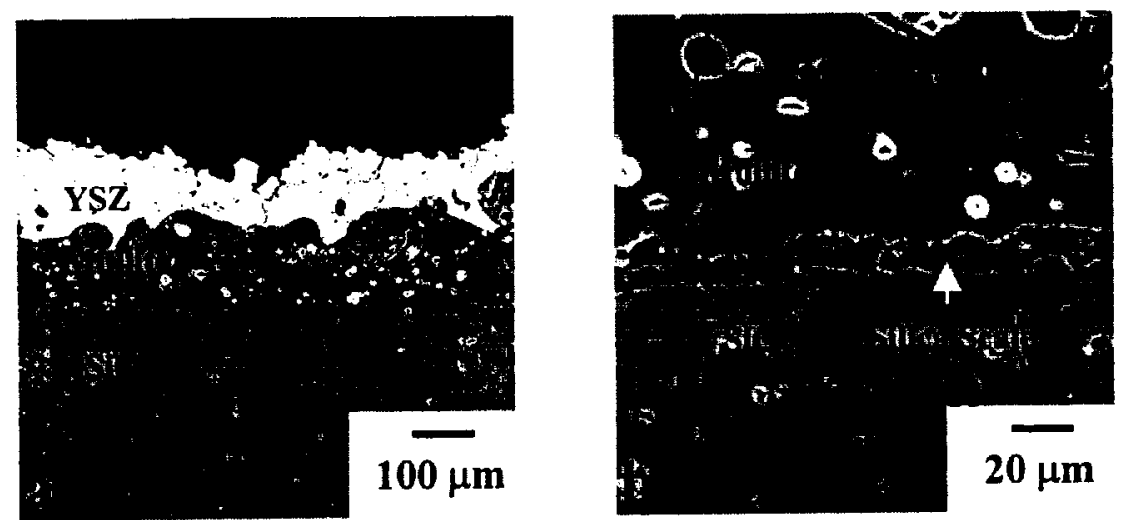

Fig. 6. Mullite/YSZ-coated SiC after $100 \mathrm{~h}$ with $2 \mathrm{~h}$ cycles in $90 \% \mathrm{H}_{2} \mathrm{O}^{\circ} \mathrm{O}_{2}$ at $1250^{\circ} \mathrm{C}$. The SiC coupon was oxidized for $100 \mathrm{~h}$ in air at $1300^{\circ} \mathrm{C}$ prior to the application of coating.
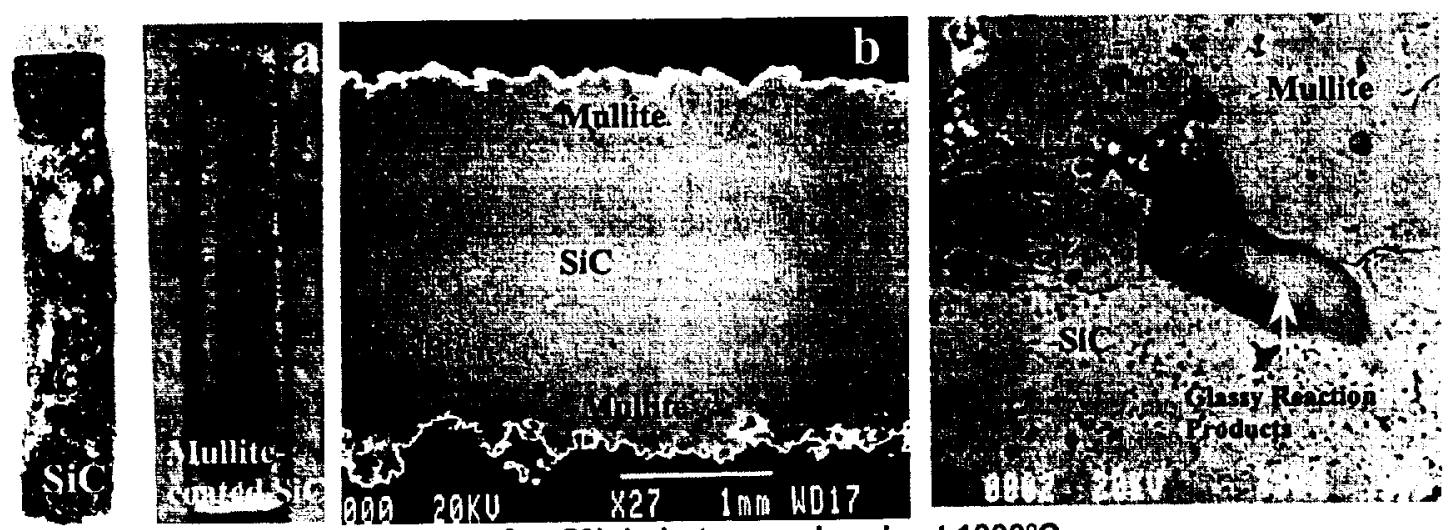

Fig. 7. Mullite-coated SiC coupon after $50 \mathrm{~h}$ in hot corrosion rig at $1000^{\circ} \mathrm{C}$.

\section{KEY ISSUES}

Several key durability issues are identified from the environmental durability test results. They include through-thickness-cracking, bonding of mullite to the Si-based ceramic, and interface contamination. These key issues will be discussed in this section to help elucidate the future research directions to improve, the coating durability. 


\section{Through-Thickness-Cracking}

As-sprayed mullite coatings are free of macrocracks (crack width $>1 \mu \mathrm{m}$ ). However, on thermal exposure, they develop through-thickness-cracks. Some cracks are as wide as $5-10 \mu \mathrm{m}$. It has been shown in the foregoing section that corrosive species, such as molten salt or water vapor, can penetrate through these cracks and attack the $\mathrm{SiC}$, leading to accelerated degradation of the system.

It is believed that the development of through-thickness-cracks is due to stresses in the coating. The most likely source for stresses is the precipitation of various second phases in the mullite coating. Amorphous phase mullite precipitates in the coating due to the rapid cooling of molten mullite [10]. Even in the second generation mullite coating, it is likely that some residual amorphous phase mullite still remains in the coating. Volumetric shrinkage results during the crystallization of the residual amorphous phase mullite in subsequent thermal exposures. A significant amount of alumina also precipitates in the plasma-sprayed mullite coating [10]. Plasma-sprayed alumina

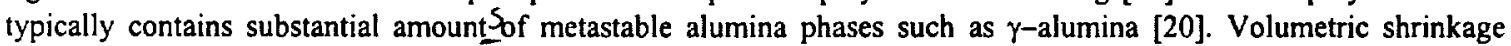
results when the metastable alumina phases transform to stable $\alpha$-alumina in subsequent thermal exposures. The precipitation of alumina phase is also accompanied by the precipitation of silica-rich phases to maintain the chemical balance [10]. Both the alumina and silica-rich phases cause CTE mismatch stresses. Thus the precipitation of second phases in the mullite coating and the resulting volumetric shrinkage and CTE mismatch are suggested to be the major sources for the stresses in the coating.

\section{Mullite/Substrate Bond}

Mullite does not form a strong chemical bond with $\mathrm{SiC}$ according to our diffusion couple study [21]. Thus the mullite/SiC bond of as-sprayed coatings is mainly due to mechanical interlocking. The lack of chemical bond may be why the oxidation propagates readily along the interface in water vapor. Silica scale from preoxidation presumably further weakens the interfacial bond, leading to more rapid attack by the water vapor.

\section{Contamination}

Also

Interfacial contamination can degrade the coating durability by altering the physical or chemical properties of silica scale. Contaminants, such as alkali or alkaline earth metal oxides, are known to be most detrimental to the oxidation resistance of Si-based ceramics [7]. They enhance the oxygen transport through silica by altering the silica network [18]. They also reduce the scale viscosity by forming silicates [22]. Pores develop at the interface when gases generated as a result of oxidation bubble through the low viscosity silica scale [17]. High interfacial porosity can eventually lead to coating delamination. Contamination from coating materials can be minimized by using high purity mullite powder or by limiting the addition of alkali or alkaline earth metal oxides in the processing of Si-based ceramics [17]

\section{FUTURE RESEARCH DIRECTIONS}

\section{Modification of Mullite Coating for Improved Crack Resistance}

Second phases that cause cracking may be reduced through process optimization. However, it may be impossible to completely eliminate all second phases. For example, melt grown mullite is always alumina-rich and thus some silica-rich phases will always be present to maintain the chemical balance $[23,24]$. The free alumina phase is likely due to the incongruent melting of mullite and thus may not be completely eliminated by process optimization. Other approaches to improve the crack resistance include modifying the physical properties of mullite coating or sealing the cracks by applying an overlay coating with good crack resistance. Figure 8 shows mullite/cordierite-coated $\mathrm{SiC}$ after $600 \mathrm{~h}$ with $20 \mathrm{~h}$ cycles at $1200^{\circ} \mathrm{C}$ in air. Note that the crack stopped at the cordierite/mullite interface. Plasmasprayed cordierite seems to be more resistant to cracking than plasma-sprayed mullite.

\section{Interface Modification for Improved Bonding}

The mullite/Si-based ceramic interface may be modified to enhance the coating/sabstrate bonding. Qne example is Mo flash layer. A Mo flash layer $(1 \sim 5 \mu \mathrm{m})$ was applied on SiC by sputtering and annealed in $\mathrm{Ar}-5 \% \mathrm{H}_{2}$ at $1200-1300^{\circ} \mathrm{C}$ for $20-100 \mathrm{~h}$, prior to the application of mullite/YSZ coating. Silicon diffused into the molybdenum forming molybdenum silicide with varying composition through the thickness [16]. Similar results were reported in a $\mathrm{Mo} / \mathrm{SiC}$ diffusion couple study $[25,26]$. The annealed flash layer was thicker and partially delaminated, presumably due to the volume expansion as the silicon diffused into the molybdenum. Figure 9 shows the mullite/molybdenum silicide/ $\mathrm{SiC}$ system after $500 \mathrm{~h}$ at $1300^{\circ} \mathrm{C}$ with $2 \mathrm{~h}$ cycles in $90 \% \mathrm{H}_{2} \mathrm{O} / \mathrm{O}_{2}$. Excellent durability was observed at some areas of the coating where the molybdenum silicide layer remained intact. Even the silica scale at the interface attacked by water vapor was thinner than the scale at the unmodified interface, indicating that the interfacial modification delayed the water vapor attack. This result suggests the potential of interface modification for improving the coating durability.

$$
\begin{aligned}
& \text { Ar example is a flosh layer of nolybolenum. }
\end{aligned}
$$

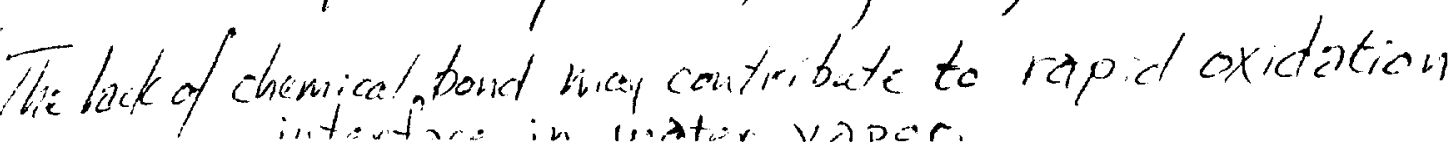

$$
\begin{aligned}
& \text { thongthe }
\end{aligned}
$$




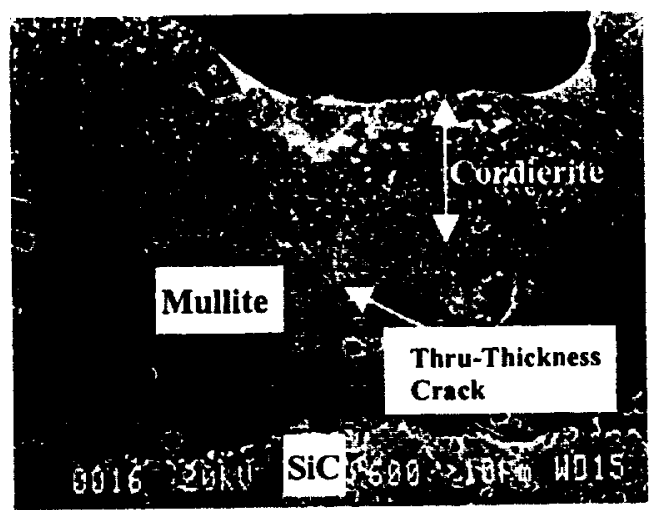

Fig. 8. Mullite/Cordierite-coated SiC after $600 \mathrm{~h}$ with $20 \mathrm{~h}$ cycles at $1200^{\circ} \mathrm{C}$ in air.

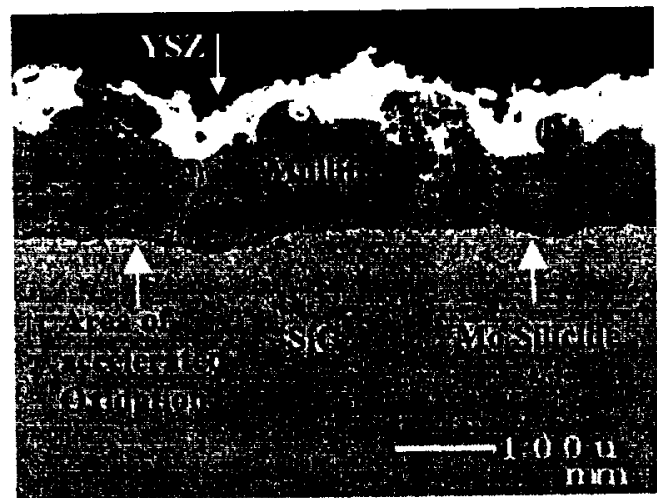

Fig. 9. Mullite/Mo Silicide/YSZ-coated SiC after $500 \mathrm{~h}$ with $2 \mathrm{~h}$ cycles at $1300^{\circ} \mathrm{C}$ in $90 \% \mathrm{H}_{2} \mathrm{O}^{\circ} \mathrm{O}_{2}$.

\section{CONCLUSIONS}

A mullite-based coating system is promising as an environmental barrier for Si-based ceramics in combustion environments. Key durability issues are through-thickness cracking in the mullite coating, a weak mullite/Si-based ceramic bond, and interfacial contamination. Improvement of the crack resistance through modification of mullite or the application of an overlay coating is suggested. Improved bonding may be achieved through the modification of interface. Interfacial contamination can be minimized by limiting impurities in coating and substrate materials.

\section{ACKNOWLEDGEMENTS}

The author would like to thank R.A. Miller (NASA-Lewis Research Center) for many helpful discussions. The author is also grateful to G.W. Leissler (Dynacs, NASA Lewis Group) for the preparation of plasma-sprayed coatings, M.D. Cuy (Dynacs, NASA Lewis Group) for the hot corrosion test, R.C. Robinson (Dynacs, NASA Lewis Group) for the HPBR test, and R. Bhatt (Army) for the supply of RBSN coupons

\section{REFERENCES}

1. N. S. Jacobson, J. L. Smialek, and D. S. Fox, "Molten Salt Corrosion of SiC and $\mathrm{Si}_{3} \mathrm{~N}_{4}$,"; pp. 99-135 in Handbook of Ceramics and Composites, Vol. 1. Edited by N.S. Cheremisinoff. Marcel Dekker, New York, 1990.

2. V. Pareek and D. A. Shores, "Oxidation of Silicon Carbide in Environments Containing Potassium Salt Vapor," J. Am. Ceram. Soc., 74 [3], 556-563 (1993).

3. A. Hashimoto, "The Effect of $\mathrm{H}_{2} \mathrm{O}$ Gas on Volatilities of Planet-Forming Major Elements: I. Experimental Determination of Thermodynamic Properties of Ca-, Al-, and Si-hydroxide Gas Molecules and Its Application to the Solar Nebula," Geochim. et. Cosmochim. Acta, 56, 511-32 (1992).

4. E. J. Opila and R. Hann, "Paralinear Oxidation of CVD SiC in Water Vapor," J. Am. Ceram. Soc., 80 [1], $197-$ 205 (1997).

5. E. J. Opila, D. S. Fox and N. S. Jacobson, "Mass Spectrometric Identification of $\mathrm{Si}(\mathrm{OH})_{4}$ from the Reaction of Silica and Water Vapor," J. Am. Ceram. Soc., 80 [4], 1009-1012 (1997).

6. F. S. Pettit and C. S. Giggins, Superalloys II (C.T. Sims, N.S. Stoloff and W.C. Hagel eds.), Wiley, New York, 327 (1987).

7. N. S. Jacobson, "Corrosion of Silicon-Based Ceramics in Combustion Environments," J. Am. Ceram. Soc., 76 [1], 3-28 (1993)

8. J. R. Price, M. van Roode, and C. Stala, "Ceramic Oxide-Coated Silicon Carbide for High-Temperature Corrosive Environments," Key Eng. Mater., 72-74, 71-84 (1992).

9. J. I. Federer, “Alumina Base Coatings for Protection of SiC Ceramics," J. Mater. Eng, 12 [2] $141-49$ (1990).

10. K. N. Lee, R. A. Miller, and N. S. Jacobson, "New Generation of Plasma-Sprayed Mullite Coatings on SiliconCarbide," J. Am. Ceram. Soc., 78 [3], 705-10 (1995). 
11. K. N. Lee, N. S. Jacobson, and R. A. Miller, "Refractory Oxide Coatings on SiC Ceramics," MRS Bulletin, XIX[10], 35-38 (1994).

12. K. N. Lee and R. A. Miller, "Oxidation Behavior of Mullite-Coated SiC and SiC/SiC Composites under Thermal Cycling between Room Temperature and 1200-1400 C," J. Am. Ceram. Soc., 79 [3], 620-26 (1996).

13. K. N. Lee and R. A. Miller, "Development and Environmental Durability of Mullite and Mullite/YSZ Dual Layer Coatings for $\mathrm{SiC}$ and $\mathrm{Si}_{3} \mathrm{~N}_{4}$ Ceramics," Surface and Coatings Technology, 86-87, 142-48 (1996).

14. N.S. Jacobson, K. N. Lee, and T. Y. Yoshio, "Corrosion of Mullite By Molten Salts," J. Am. Ceram. Soc, 79 [8], 2161-67 (1996).

15. K. N. Lee, R. A. Miller, N. S. Jacobson, and E. J. Opila, "Environmental Durability of Mullite Coating/SiC and Mullite-YSZ Coating/SiC Systems," Ceram. Eng. \& Sci. Proc., September-October, 1037-1044 (1995).

16. K. N. Lee and R. A. Miller, "Durability of Mullite/YSZ-Coated $\mathrm{SiC}$ in $90 \% \mathrm{H}_{2} \mathrm{O} / \mathrm{O}_{2}$," in press (Advances in Ceramic-Matrix Composites).

17. K. N. Lee, "Contamination Effects on Interfacial Porosity During Cyclic Oxidation of Mullite-Coated SiC," in press (J.Am. Ceram. Soc.)

18. M. A. Lamkin, F. L. Riley, and R. L. Fordham, "Oxygen Mobility in Silicon Dioxide and Silicate Glasses," $J$. Eur. Ceram. Soc., 10, 347-67 (1992).

19. K. N. Lee and R. A. Miller, "Modification of Mullite-Based Coatings on Si-Based Ceramics for Enhanced Durability," HITEMP Review, Volume III, NASA Lewis Research Center, Cleveland, OH, 45 (1997).

20. G. N. Heintz and U. Uematsu, "Preparation and Structures of Plasma-Sprayed $\gamma$ and $\alpha$-alumina Coatings," Surface and Coatings Technology, 50, 213-22 (1992).

21. K. N.Lee, NASA Lewis Research Center, unpublished research.

22. D. G. Holloway, The Physical Properties of Glass, Ch. I. Wykeham Publications Ltd, London, U.K., 1973.

23. I. A. Aksay and J. A. Pask, "Stable and Metastable Equilibria in the System $\mathrm{SiO}_{2}-\mathrm{Al}_{2} \mathrm{O}_{3}$," J. Am. Ceram. Soc., 58 [11-12], 507-12(1975).

24. W. M. Kriven and J. A. Pask, "Solid Solution Range and Microstructure of Melt-Grown Mullite," J. Am. Ceram. Soc., 66 [9], 649-54 (1983).

25. A. E. Martinelli, R.A.L. Drew, "Microstructure Development during Diffusion Bonding of $\alpha$-Silicon Carbide to Molybdenum," Mat. Sci. And Eng. A, 191, 239-247 (1995).

26. A. E. Martinelli, R.A.L. Drew and R. Berriche, "Correlation Between the Strength of SiC-Mo Diffusion Couples and the Mechanical Properties of the Interfacial Reaction Products," J. Mat. Sci. Letters, 15, 307-310 (1996). 
$\|$ 